\title{
Dutch Disease-cum-financialization Booms and External Balance Cycles in Developing Countries
}

\author{
Booms de Financeirização com Doença Holandesa e Ciclos \\ Externos em Países Desenvolvidos
}

ALBERTO BOTTA*

RESUMO: Neste artigo nós investigamos a dinâmica de médio a longo prazo que emerge do fenômeno da doença holandesa com financeirização. Nós nos inspiramos no caso mais recente do padrão de desenvolvimento da Colômbia. A doença holandesa "pura" causa desindustrialização, em primeiro lugar, ao apreciar permanentemente a taxa de câmbio no longo prazo. A financeirização neste caso, isto é, os maiores influxos de capital em um cenário de excesso de otimismo financeiro puxado pela existência de recursos naturais, leva no médio prazo a uma maior volatilidade na taxa de câmbio e à instabilidade macroeconômica. Este processo prejudica ainda mais o desenvolvimento do setor manufatureiro ao aumentar a incerteza na economia. A recomendação é, portanto, pela adoção do controle de capitais e por uma política monetária desenvolvimentista a fim de confrontar os fenômenos da financeirização e da doença holandesa.

PALAVRAS-CHAVE: Doença holandesa; financeirização; volatilidade cambial; política monetária desenvolvimentista.

ABSTRACT: We formally investigate the medium-to-long-run dynamics emerging out of a Dutch disease-cum-financialization phenomenon. We take inspiration from the most recent Colombian development pattern. The "pure" Dutch disease first causes deindustrialization by permanently appreciating the economy's exchange rate in the long run. Financialization, i.e., booming capital inflows taking place in a climate of natural resource-led financial overoptimism, causes medium-run exchange rate volatility and macroeconomic instability. This jeopardizes manufacturing development even further by raising macroeconomic uncertainty. We advise the adoption of capital controls and a developmentalist monetary policy to tackle these two distinct but often intertwined phenomena.

KEYWORDS: Dutch disease; financialization; exchange rate volatility, developmentalist monetary policy

JEL Classification: F32, O14, O24.

\footnotetext{
"Department of International Business and Economics, University of Greenwich. E-mail: A.Botta@ greenwich.ac.uk. Submitted: 7/April/2016; Approved: 28/July/2016.
} 


\section{NATURAL RESOURCE BOOMS, CAPITAL INFLOWS AND EXTERNAL BALANCE DYNAMICS IN DEVELOPING COUNTRIES}

In the last two decades, several economists have supported the idea that financial liberalization and free capital movements can be relevant causes of macroeconomic volatility. Their concern was mainly about volatile portfolio investment. Foreign Direct Investment (FDI) is usually positively considered instead. In the case of developing countries, it is believed to contribute to domestic capital formation and enhance labor productivity through the "import" of more advanced technologies.

FDI's positive contribution to economic progress in developing countries cannot be taken as given. It depends on the way FDI integrates into the productive system of the recipient economy. The sectorial pattern of incoming FDI is likely to be a decisive factor. In instance, FDI in the manufacturing sector may foster longterm growth by spreading technological progress, and by possibly weakening external balance constraints through the diversification of the domestic productive structure. On the contrary, natural resource-oriented FDI very often constitutes separate enclaves within the productive system of the host economy, and could give rise to Dutch disease by increasing the economy dependence on natural resource industries.

There is an abundant literature on the Dutch disease and on its possible causes. Corden and Neary (1982), Sachs and Warner (2001), and Ros (2001) propose supply-side models that describe the Dutch disease as emerging from natural resource booms. Taylor (1983) and Bresser-Pereira (2008, 2010, 2013) address such a topic into structuralist heterodox frameworks. Several empirical studies broaden the concept of Dutch disease and attribute Dutch disease-like effects to a variety of foreign resource inflows, foreign aid, emigrants' remittances, and different types of capital inflows alike.

These contributions rely upon rather different theories and adopt different approaches. Nevertheless, most of them share a common vision of the Dutch disease as a real-side phenomenon that manifests itself through real-side mechanisms. They maintain the same perspective as developed in Corden and Neary (1982), and "ignore monetary considerations and focus on [natural resource booms'] implications for real rather than nominal variables (Corden and Neary, 1982, p. 825)". In particular, they do not consider the repercussions that the increasing exploitation and export of natural resources may trigger off on the medium/long-run dynamics of an economy by affecting the external balance account and the determination of the nominal exchange rate.

Bresser-Pereira (2008, 2010, 2013), and Bresser-Pereira et al. (2014) have recently developed a different approach addressing such a shortcoming. BresserPereira (2010), for instance, efficaciously describes the Dutch disease as a long-run structural phenomenon according to which the exploitation of abundant and cheap resources induces a "chronic overvaluation of a country's exchange rate [which is] clearly more appreciated than the average exchange rate that makes tradable goods industries economically viable [and therefore] obstruct industrialization [or] pro- 
vokes deindustrialization (Bresser-Pereira, 2010, pp. 149-150)”. The Dutch disease is therefore "consistent with the intertemporal equilibrium of foreign accounts [... but] implies the existence of a difference between the exchange rate that balances the current account and the exchange rate that enables efficient and technologically sophisticated economic sectors (Bresser-Pereira, 2010, p. 150)".

The aim of this paper is to contribute to the literature on the Dutch disease and the effects of natural resource-oriented FDI on both the medium and long-run economic dynamics of developing countries. We closely follow Bresser-Pereira's approach and his definition of Dutch disease. In this sense, we model the permanent appreciating effect that the exploitation and export of domestic natural resources can have on the exchange rate this way dampening long-run manufacturing development and productivity growth. Beyond this, we try to extend Bresser-Pereira's analysis by describing the volatile medium-run macroeconomic dynamics that may emerge when the Dutch disease comes with booming natural resource-oriented FDI and, more in general, with the financialization ${ }^{1}$ of the recipient economy. In doing so, we take inspiration from the most recent Colombian development pattern, the so-called "locomotora minero-energetica" according to the emphatic rhetoric of the Colombian government. The kind of medium-run dynamics we describe start from FDI targeting developing countries' natural resources and affecting their external balance equilibrium. Following Singh (2003), in a flexible exchange rate regime long-term FDI induces the exchange rate to appreciate. Exchange rate appreciation, which is first nominal and then real, in turn attracts additional portfolio investment by reducing perceived country risks or increasing capital gains' expectations. Portfolio capital inflows feed back on exchange rate dynamics and lead to an even stronger appreciation. However, these self-reinforcing mechanisms may not last long. Rather, they may eventually reverse when economic agents realize that they have gone too far and medium-run exchange rate appreciation and the accumulation of foreign debt has been excessive.

We describe two undesirable outcomes that can arise from such a medium-tolong-run dynamics. First, the increasing exploitation and export of domestic natural resources causes a permanent nominal and real appreciation of the exchange rate (with respect to that one consistent with manufacturing development). Following Bresser-Pereira (2008, 2010, 2013), this is the "pure" Dutch disease phenomenon, which in this paper materializes through financial and monetary mechanisms (i.e., the determination of the nominal exchange rate on financial markets) rather than the real-side ones (i.e., spending effects modifying the relative price of tradable versus non-tradable goods) generally put at the center of traditional Dutch disease

\footnotetext{
${ }^{1}$ Financialization is a very broad and not well-defined concept. Here we use this term to define the climate of exuberance and rising interests of international financial operators in investing in developing countries following the occurrence of a sort of "structural break" event. In this paper, such a "break" takes the form of a natural resource boom. This may play the same role that radical regime changes, say financial liberalization or the privatization of state-owned companies in the context of restrictive macro policies, historically covered in several developing economies (see Taylor, 1991, ch. 6).
} 
models. Second, when the Dutch disease comes along with the financialization of the economy, i.e., booming natural resource-oriented FDI and portfolio investment, such long-run exchange rate appreciation may be accompanied by medium-term exchange rate volatility and macroeconomic instability. A developing country-type Minskyan cycle may easily take place (see Frenkel and Rapetti, 2009; Harvey, 2010). A sharpened exchange rate volatility and the ensuing macroeconomic instability can lower manufacturing development and long-run growth potential even further since that productive investment in manufacturing is usually highly sensitive to this type of instability.

The kind of Dutch disease-cum-financialization model we present has the virtue to highlight two aspects of exchange rate dynamics, and hence of its policy management, which are both relevant to manufacturing and long-run economic development of developing countries. The first aspect is the need to maintain a competitive real exchange rate by managing the nominal one (among other variables). We explicitly consider this point when we deal with the long-run effects of natural resource booms on manufacturing development (Third Section). The second perhaps more neglected aspect is the need to keep such a competitive exchange rate stable. This aspect is addressed when we analyze the medium-run volatile macroeconomic dynamics emerging from booming capital inflows directly or indirectly associated to the natural resource boom itself and the (vulnerable) euphoric climate it may temporarily trigger (Second Section). In this regard, our paper is an extension of some traditional Dutch disease models that formalize external imbalances into perfect-foresight infinite-lifetime frameworks, and therefore neglect exchange rate volatility and macroeconomic instability by assumption, since that external borrowing and rising foreign debt today are fully and safely repaid by increasing domestic savings and rising current account surpluses tomorrow (see Bruno and Sachs, 1982; Mansoorian, 1991). On the contrary, our model tries to merge together the existing literature on natural resource booms and the Dutch disease, with the longstanding heterodox concern for Minskyan exchange rate-external debt cycles (see Frenkel and Rapetti, 2009; Harvey, 2010) and Balance of Payments (BoPs)-dominance regimes (Ocampo, 2013) that recurrently unfold and shape, or better restrain, economic development in developing countries.

\section{NATURAL RESOURCE-CUM-FINANCIALIZATION BOOMS AND MEDIUM-RUN MACROECONOMIC INSTABILITY}

Since mid-2000s, Colombia has increasingly attracted the attention of financial operators as a promising growing economy where to invest and realize high returns. The Economist Intelligence Unit (2013), for instance, describes Colombia as a “[...] success story [which] is now one of the most open and most business-friendly countries in Latin America [... and in which] new opportunities are opening up for foreign investors, particularly in hydrocarbons and mining, construction, and electricity (EIU, 2013, p. 8)". 
Despite of foreign investors' enthusiasm about Colombian development, in a previous empirical work we documented some disturbing facts that may undermine Colombia's bright future:

1. The recent development of the Colombian economy has been mainly driven by the expansion of the domestic energy and mining sector, oil in particular. The expansion of the Colombian mining industry has been largely driven by massive FDI targeting Colombian natural resources. Since 2005, it has accounted for 50 percent or more of total FDI, and has amounted to more than 2 percent yearly of Colombian GDP.

2. The increasing exploitation and export of Colombian natural resources, as accompanied by massive net FDI inflows, have come at the cost of jeopardizing Colombian manufacturing development. Since mid 2000s, the Colombian manufacturing sector has shrank, both in relative terms with respect to mining and service and, sometimes, even in absolute terms. There is widespread consensus that the Dutch disease is underway in Colombia (Goda and Torres, 2013; OECD, 2013).

3. According to the literature just mentioned, the contraction of Colombian manufacturing is due to the appreciation of the Colombian real exchange rate, which has made Colombian homemade manufactured goods increasingly uncompetitive on both the international goods market and into the home economy. Let's define the Colombian real exchange rate as $q=e P_{F}$ ' $P_{H}$, where " $e$ " is the nominal exchange rate, " $P_{F}$ " is the foreign consumer price index (in foreign currency), and " $P_{H}$ " is the home economy's consumer price index (in Colombian pesos). From 2003 to 2014, the Colombian nominal exchange rate appreciated (i.e., " $e$ " decreased) by 5,7 percent yearly, whilst real appreciation (i.e., a reduction in " $q$ ") was in the order of 5 percent yearly only. According to the IMF's 2014 World Economic Outlook, the inflation targeting monetary policy implemented by the Colombian central bank has been effective in keeping Colombian inflation under control. Colombian inflation has declined since 2008. It has been significantly lower than that observed in other emerging economies, and sometimes close to that registered in developed economies. According to these facts, the appreciation of the Colombian real exchange rate has been primarily driven by nominal dynamics and by the determination of the nominal exchange rate on the currency market rather than by real factors linked to (relative) inflation dynamics (i.e., changes in consumer price indexes). In the flexible exchange rate regime characterizing Colombia, increasing primary commodities' exports and massive FDI inflows have been the leading forces behind the appreciation of the Colombian nominal, and hence real exchange rate. Both flows have jointly contributed to determine a remarkable financial account surplus outstripping a modest trade account deficit, this way generating an excess demand for Colombian pesos in the currency market. 
4. Due to an euphoric investment climate surrounding Colombia and deriving from its natural resource boom, increasingly positive net portfolio investment has followed the initial surge in FDI, this way inflating the demand for Colombian pesos even further. Considerable portfolio investment has been attracted by the expectation for a persistent Colombian pesos appreciation making foreign currency-denominated external financing cheaper (from the point of view of potential Colombian borrowers), and/or capital gains on Colombian assets higher (from the point of view of foreign investors). According to the Colombian central bank, net portfolio investment flows in Colombia were almost zero (or negative) in the first half of the 2000s. Since 2007 (and with the only exception of 2008) they have exhibited positive values. From 2011 to 2013, they amounted to more than 5.5 billion dollars yearly, more than $1.5 \%$ of Colombian GDP. In the first quarter of 2014, it stood at more than 2.5 billion dollars.

5. In line with the stylized facts described at points (1) - (4), a standard BoP current account deficit-with-foreign saving financing has emerged in Colombia. Mounting FDI first and portfolio investment later have financed a widening Colombian current account. Despite of rising oil exports and high and increasing prices of primary commodities until the end of 2014, since 2003 the Colombian trade balance has been slightly positive only in 2011. This undesirable dynamics is the outcome of a large and widening manufacturing trade balance deficit around 10 percent of GDP. Moreover, the Colombian overall current account has registered considerable deficits due to booming profits repatriation by foreign firms operating in the Colombian mining sector mainly. According to the IMF (2015), the drop in the oil price that has been taking place since the last months of 2014 is expected to worsen the Colombian current account balance even further, and bring it close to 5,9 percent of GDP in 2015.

6. The recent drop in the international price of oil and the slowdown in FDI has triggered off, since the end of 2014, a reversal in the Colombian exchange rate dynamics. Such a reversal raises serious doubts about the external solidity of Colombia. According to the IMF (2015), the decline in oil price, as well as the increasing dependency on portfolio investment to finance current account deficits, "could lead to sharp repricing of Colombian assets and exchange rate [... and] could lead to heightened vulnerability to global financial volatility (IMF, 2015)".

In the present paper we adopt an inductive approach. We take the Colombian stylized facts as the starting point in order to develop a more general model that formally describes the above macroeconomic dynamics, the economic mechanisms behind them, and the possible threats posed to Colombian (and perhaps other resource abundant economies) development by both the long-run consequences of the Dutch disease and the medium-run implications of a (BoPs) current account deficit-cum-foreign saving financing development pattern. In doing this, the medi- 
um-run part of our model formalizes the argumentative analyses by Frenkel and Rapetti (2009), and Harvey (2010) of developing country-type external account Minskyan cycles.

Let's assume a small open developing economy exhibiting three characteristics. First, the economy has a significant endowment of natural resources. Second, the economy is open to free capital movements. Both long-term FDI and short/mediumterm portfolio investment are allowed. For the sake of simplicity, we assume FDI to concentrate in the natural resource sector only. Portfolio investment takes mainly the form of short/medium-term foreign debt (denominated in foreign currency). ${ }^{2}$ Equities are not considered, but such simplification does not modify the logic of our model and the economic mechanisms we are investigating. Third, the primary objective of monetary policy is price stability, and it is implemented via inflation targeting. Consistently with an inflation targeting monetary policy, the nominal exchange rate is free to float (Mishkin, 2000; Epstein and Yeldan, 2009).

In this paper, we focus on the medium-to-long-run economic dynamics that may unfold in a resource abundant developing country when a resource booms takes place, and it attracts FDI first and portfolio investment later by stimulating an euphoric investment climate. We therefore neglect to describe short-run mechanisms. We take inspiration from Taylor (2004, ch. 10), who describes a prototype developing country's external balance cycle in the case of a fixed exchange rate regime. According to the purposes of our analysis, and in light of the stylized facts we described, we adapt Taylor's dynamic equations to the case of a flexible exchange rate setting. We do that in equation (1):

$$
\dot{e}=e\left\{\left[\operatorname{imp}_{M}(q(e))-\frac{\exp _{m}(q(e))}{e}\right]-\exp _{N R}+i_{H} D+\pi_{N R}+\dot{R}-K A_{P I}\left(i_{H}-i_{F}-\sigma(e, D)\right)-K A_{F D I}(N)\right\}
$$

Taylor (2004, ch. 10) explains the evolution of a country's foreign reserves as the endogenous outcome of the interaction among various components of the corresponding BoPs. In our model, foreign reserves are an exogenous policy variable in the hands of domestic monetary authorities through which they may try to control the nominal exchange rate dynamics. In equation (1), the interplay between the several components of the BoPs current and financial accounts now determines the dynamics of the nominal exchange rate. Following Taylor (2004, ch. 10), equation (1) does not show the standard Mundell-Fleming dichotomy between a flexible exchange rate and endogenous foreign reserves as adjusting variables for short-run external imbalances. Equation (1) does not determine any instantaneous equilibrium level of the nominal exchange rate $e$. It simply takes into account some factors included in the BoPs, i.e., trade flows, net income transfers, and financial flows, that

\footnotetext{
${ }^{2}$ See Taylor (1998), Neftci (1998) and Frenkel and Rapetti (2009) on the short-term structure of foreign liabilities of domestic agents, financial intermediaries in particular, in the emerging economies affected by financial and currency crises in 1990s.
} 
may drive the evolution of the nominal exchange rate by influencing the excess demand or excess supply for the domestic currency on the currency market. Equation (1), for instance, shows that nominal exchange rate dynamics is strongly influenced by interest rate differentials and country-factor risk premiums, which modify portfolio investment decisions and net portfolio capital flows, hence determining changes and temporary trends in the exchange rate dynamics $\dot{e}$.

In equation (1) we put emphasis on those components of the BoPs that may be of relevance to formally grasp the stylized facts described above. Equation (1) distinguishes between imports and exports of manufactured goods as expressed in foreign currency, $i m p_{M}$ and $\left(\exp _{M} / e\right)$ respectively; foreign currency-denominated exports of domestic natural resources $\exp _{N R}$, say oil; interest payments on foreign debt $i_{H} D$; foreign firms' profit repatriation out of natural resource revenues $\pi_{N R}$; exogenous central bank-driven variations of foreign reserves $\dot{R}$; net portfolio capital inflows $K A_{P I}$, and net FDI $K A_{F D I}$. We assume that foreign firms' profit repatriation $\pi_{N R}$ is a constant share $\alpha$ of natural resource exports $\exp _{N R}$.

In equation (1), manufactured goods imports $\left(i m p_{M}\right)$ are denominated in foreign currency. According to standard economic theory on trade account dynamics (see the BoPs-constrained growth models à la Thirlwall, for instance), they respond negatively to real exchange rate depreciations (i.e., higher $q$ values), which make them relatively more costly and less competitive with respect homemade goods. Manufactured goods exports $\left(\exp _{M}\right)$ are denominated in domestic currency and respond positively to the depreciation of the real exchange rate. The overall value (in foreign currency) of the manufactured goods trade balance responds positively or negatively to real exchange rate shifts depending on the fulfillment of the Marshall-Learner condition as applied to the "restricted" case of manufactured goods trade (see below).

The dynamics of the real exchange rate depends on both nominal/monetary forces (the evolution of the nominal exchange rate on financial markets) and realside factors (relative inflation rate dynamics). Nonetheless, here we follow BresserPereira $(2008,2010,2013)$ and we focus on the monetary aspects of the story only. We do this on the basis of the Colombian experience reviewed before, and due to three main reasons. First, traditional Dutch disease models have almost completely neglected to consider nominal factors influencing the real exchange rate dynamics. However, this is a crucial part of the story, perhaps the most relevant one, if one wants to analyze the effects of increasing natural resource exports on the determination of the external balance equilibrium, the real exchange rate and hence manufacturing development in a consistent full-fledged macro-accounting framework. This is even more so when the Dutch disease comes with huge natural resource-oriented FDI and, more in general, the financialization of the home economy. Second, inflation targeting monetary policy can at least partially restrain inflation lifts due to abundant capital inflows. Relative inflation rate dynamics among trading partners may be of minor concern with respect to what observed in the past in presence of fixed exchange rate regimes. Third, developing countries' inflation may easily reach higher levels than those observed in foreign economies - developed ones in particular (see Frenkel and Rapetti, 2009). Therefore, the inclusion in our 
model of changes in inflation rate differentials would simply reinforce the kind of dynamics we already illustrate. For the sake of simplicity, we neglect to explicitly model the role played by inflation rate differentials among trading partners to explain the evolution of the real exchange rate.

In the case of developing countries, foreign portfolio investment in debt instruments mostly takes the form of foreign currency-denominated short/medium-term debt (Mishkin, 2000). Accordingly, foreign lenders do not bear any direct exchange rate risk. The amount of net portfolio capital inflows is simply determined by the interest rates' differential $\left(i_{H}-i_{F}\right), i_{H}$ and $i_{F}$ being the domestic and foreign interest rates respectively, ${ }^{3}$ and by the country-specific factor risk $\sigma$. Yet, portfolio net capital flows are related to exchange rate dynamics through the lender-borrower default risk. An appreciation of the domestic nominal exchange rate (i.e., a decreasing $e$ value) helps domestic borrowers to meet their payment commitments (in foreign currency) more easily. It follows that the country factor risk decreases and portfolio investment increases. In the same vein, a depreciation of the exchange rate makes the foreign debt burden less sustainable and domestic borrowers' default risk higher. In this case, the ensuing increase in the country-specific risk factor $\sigma$ curtails (and perhaps reverse) net portfolio capital flows. Therefore, the domestic exchange rate and short/medium-term portfolio capital flows are connected by an indirect negative relationship.

Net FDI $K A_{F D I}$ is assumed not to depend on the exchange rate, since it targets domestic natural resources that are exported on international markets and sold in foreign currency. It is positively influenced by the available stock of domestic natural resources $N$.

Equation (2) makes explicit our assumption of net portfolio capital flows mainly consisting of short/medium-term bonds, thus representing foreign debt variations:

$$
\dot{D}=K A_{P I}\left(\left(i_{H}-i_{F}-\sigma(e, D)\right) \quad \text { with } \frac{\partial K A_{P I}}{\partial \sigma}<0 ; \frac{\partial \sigma}{\partial e}>0 ; \frac{\partial \sigma}{\partial D}>0\right.
$$

Equation (2) also states a reasonable negative relationship between the current level of foreign indebtedness $D$ and its own dynamics. The higher the foreign debt stock is, the less likely foreign lenders are to increase their exposition towards domestic economic agents by providing new credit. Therefore, there exists a negative self-stabilizing relationship in the accumulation of foreign debt between $D$ and $\dot{D}$

In order to study how exchange rate changes feed back on its own dynamics, take the partial derivative of equation (1) with respect to the nominal exchange rate in the neighborhood of the steady state. We get:

$$
\left.\frac{\partial \dot{e}}{\partial e}\right|_{\dot{e}=0}=\frac{\exp _{M}}{e}\left\{\eta_{\text {imp }_{M}}^{e} \chi-\eta_{\exp _{M}}^{e}+1\right\}-e \frac{\partial K A^{P I}}{\partial \sigma} \frac{\partial \sigma}{\partial e}
$$

\footnotetext{
${ }^{3}$ We assume the domestic interest rate $i_{H}$ to be an exogenous policy variable set by the domestic central bank in order to achieve its inflation target.
} 
With $\chi=\frac{i m p_{M}}{e x p_{M} / e}$ as the manufacturing import-export $\operatorname{ratio} ; \frac{e \frac{\partial i m p_{M}(e) / \partial e}{i m p_{M}}}{i \eta_{i p_{N}}^{e}}$ and $e \frac{\left(\partial \exp _{W}(e) / \partial e\right.}{\exp _{M}}=\eta_{\text {eqp }}^{e}$ as manufactured goods import and export elasticities to the exchange rate.

Equation (3) defines the negative or positive effect that an exchange rate shift has on its own dynamics. The first part of equation (3) is the well-known MarshallLearner condition in the case of an initial (manufacturing) trade imbalance. In the last decades, financial deregulation has made financial transactions overwhelmingly relevant in explaining exchange rate dynamics. Correspondingly, the second part of equation (3) takes into account how an exchange rate shift may affect net capital flows, portfolio investment in particular. The sign of equation (3) can be either negative (a depreciated exchange rate tames further depreciation) or positive (unstable feedbacks in the exchange rate dynamics). In this regard, the more liberalized the capital account is, the more intensively capital movements respond to exchange rate shifts. This fact likely outstrips possible stabilizing effects passing through trade flows, and gives rise to exchange rate instability. In the rest of the paper we investigate such unstable scenario.

The effect of a higher foreign debt stock $D$ on the exchange rate dynamics is clearly positive. First, an increase in $D$ leads foreign lenders to be more skeptical about new credit lines granted to the home economy, so that $(\partial \sigma / \partial D)>0$. Portfolio investment might probably decrease as well as the demand for domestic currency does. Second, higher debt stocks imply tougher debt burdens and heavier interest payments. The demand for foreign currency increases and the domestic exchange rate depreciates. The positive link between $D$ and $\dot{e}$ is formally stated in the derivative below:

$$
\left.\frac{\partial \dot{e}}{\partial D}\right|_{\dot{e}=0}=e i_{H}-e \frac{\partial W A_{P I}}{\partial \sigma} \frac{\partial \sigma}{\partial D}>0
$$

According to the economic relationships encapsulated in equations (1) and (2), dynamics in the exchange rate and foreign debt stock can be described according to the Jacobian matrix J:

$$
J=\begin{array}{ccc}
\dot{e} & e & D \\
\dot{D} & {\left[\begin{array}{ll}
+ & + \\
- & -
\end{array}\right]}
\end{array}
$$

The signs of partial derivatives in matrix $J$ reveal that both geometric loci for constant values of $e$ and $D$ slope downward. A locus for $(\dot{D}=0)$ that is flatter than the isocline for $(\dot{e}=0)$ gives rise to a focus. Cyclical fluctuations around the equilibrium point $A$ will be stable and convergent to equilibrium should the Jacobian matrix's trace tr. $(J)$ be negative. Possible (converging) fluctuations and exchange rate volatility characterizing such economy are portrayed in Figure 1. 
Figure 1: Joint medium-run cycles in the exchange rate-foreign debt space

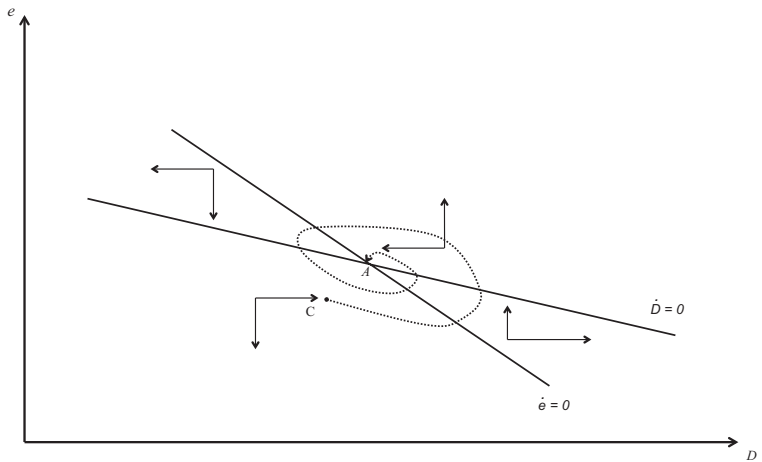

Let us assume now that new natural resources are discovered. This fact likely leads to a spike in net FDI targeting domestic natural resources. At the same time, primary commodity's exports $\exp _{N R}$ increase due to the natural resource boom itself. From a graphical point of view, both facts shift the isocline for $(\dot{e}=0)$ to the right (see Figure 2). A new equilibrium point $B$ emerges. Two different but strictly intertwined processes unfold.

Figure 2: Fluctuations induced by an initial surge in FDI

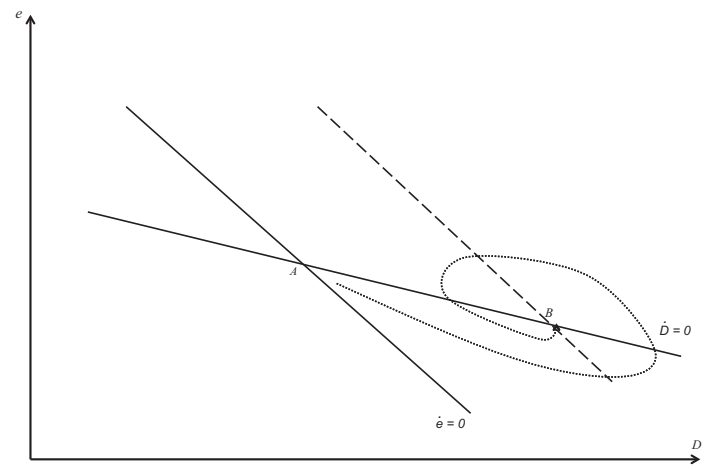

First, a permanent long-term appreciation of the nominal and hence real exchange rate takes place in the transition from equilibrium $A$ to equilibrium $B$. This is due to the increase in primary commodity exports, which makes the exchange rate consistent with the external balance equilibrium persistently more appreciated than the exchange rate that would make domestic industrial development viable. This is the "pure" long-run Dutch disease effect as described by Bresser-Pereira (2008, 2010, 2013), and Bresser-Pereira et al. (2014). Such a long-lasting appreciation is even reinforced by the surge in natural resource-oriented FDI.

Second, the traverse from the old equilibrium to the new one is not monotonic, but it is characterized by sharpened exchange rate volatility (see the dotted trajectory in Figure 2). In the medium run, the initial appreciation of the exchange 
rate (as due to mounting FDI and increasing natural resource exports) attracts additional short/medium-term portfolio investment. Mounting foreign portfolio investment in turn induces the exchange rate to appreciate even further so that the short/medium-run exchange rate appreciation temporarily overshoots the long-run one. However, such a dynamics will not last long. FDI inflows, portfolio investment, and the increasing export of natural resources jointly contribute to crowd out manufactured goods exports and trigger a widening manufacturing trade deficit by appreciating the nominal (and real) exchange rate itself. Such a widening manufactured goods trade account deficit, together with foreign firms' profit repatriations (i.e., increasingly negative net income payments) determines, soon or later, an overall external deficit and downward pressures on the domestic currency (i.e., a positive value of $\dot{e}$ ). Portfolio investment will first stop and then reverse together with the exchange rate dynamics. Eventually, the initial surge in natural resource-oriented FDI ignites a standard developing country external account cycle characterized by exchange rate volatility, macroeconomic instability and disruption in economic activity (see Taylor, 2004). ${ }^{4}$

Very importantly, following Rodrik (2007), both the long-run Dutch diseaseinduced permanent appreciation of the exchange rate, and the medium-run (capital flow-led) exchange rate volatility likely undermine manufacturing development. Indeed, manufacturing sector firms have to plan production and export activities ahead of effective sales, and take investment decisions with a long-term horizon profile. From their point of view, there is a big difference between a managed devaluation of the nominal exchange rate, which is aimed (by domestic monetary institutions) at maintaining a stable and competitive real exchange rate, and a temporary devaluation, which is a transitory phase of a more general and permanent process of real exchange rate appreciation, and that results from sharpened exchange rate volatility very often associated with macroeconomic instability and economic slowdown, if not contraction (see Taylor 2004; Frenkel and Rapetti, 2009). The former scenario creates a reliable and optimistic environment in which manufacturing firms can take their decisions. On the contrary, the medium-run volatile scenario we describe is the source of heightened uncertainty discouraging firms from implementing investment projects whose profitability cannot be assessed with enough (Keynesian-type) confidence. This is why, in such a scenario, temporary exchange rate reversals and transitory devaluations give a very poor contribution, if any, to the promotion of domestic manufactured goods exports and overall domestic manufacturing development. ${ }^{5}$

\footnotetext{
${ }^{4}$ Mishkin (2000, p. 6) notes that "in many emerging market countries the balance sheets of firms, households and banks are substantially dollarized [...] Since inflation targeting necessarily requires nominal exchange rate flexibility, exchange rate fluctuations are unavoidable. A large depreciation may increase the burden of dollar-denominated debt and produce a massive deterioration of the balance sheets, increasing the risks of a financial crisis".

${ }^{5}$ See Fang et al. (2009), and Oreiro et al. (2014) for empirical investigations on the negative effects that exchange rate volatility induces on manufactured goods exports and manufacturing development,
} 


\section{LONG-RUN CONSEQUENCES OF A DUTCH \\ DISEASE-CUM-FINANCIALIZATION BOOM}

Let's now have a deeper look at the long-run development trajectory emerging out of the medium-run dynamics described above, and due to the Dutch diseasecum-financialization process we are describing. Consider first the considerable body of literature that identifies in a depreciated, competitive and stable real exchange rate one of the most effective macroeconomic variables boosting the expansion of manufacturing versus non-tradable goods industries (Gala, 2008; Rodrik, 2008, 2009; Bresser-Pereira, 2008, 2010, 2013; Cimoli et al., 2013). Equation (4) formalizes in the simplest way possible this point by making manufacturing development, here proxied by manufacturing contribution to real GDP, a negative function of an appreciated nominal exchange rate (i.e., a low " $e$ " value) that appreciates the real one $q$. Nominal and real exchange rate appreciations dampen domestic manufacturing development by making homemade manufactured goods more expensive and less competitive than foreign ones, hence curtailing the demand that domestic manufacturing firms can potentially satisfy. Secondly, following Bresser-Pereira (2008, 2010, 2013), exchange rate appreciations make domestic manufacturing not economically viable by squeezing its profitability with respect to competing industries in foreign countries, and with respect other non-manufacturing sectors in the home economy.

(4) $m=f\left(q(e), \rho, W A_{P I}, K_{N R}\right)$ with $\frac{\partial m}{\partial q} \frac{\partial q}{\partial e}>0 ; \frac{\partial m}{\partial \rho}<0 ; \frac{\partial m}{W A_{P I}}<0 ; \frac{\partial m}{\partial K_{N R}}<0$

Equation (4) also grasps the implications of the medium-run dynamics described in the previous section and of the connected empirical evidence according to which exchange rate volatility (on top of long-run appreciation) can seriously hinder manufacturing development. In equation (4), $\rho$ stands for a measure of exchange rate volatility, namely exchange rate variance. Perverse feedbacks between initial FDI flows, short/medium-term portfolio investment and exchange rate dynamics may give rise to exchange rate fluctuations and volatility, i.e., increasing $\rho$ values, that put further strain on domestic manufacturing development.

In equation (4), we also assume a negative relationship between manufacturing development and net portfolio capital inflows. Economic analysis has mostly focused on the effects of portfolio investment on general macroeconomic volatility rather than on the sectorial composition of the economy. Nonetheless, non-tradable sectors are very likely those sectors that can benefit most from a surge in portfolio foreign investment. Following Taylor (1991, ch. 6; 1998), financial services or the

perhaps more than compensating for the positive effect that a "managed" exchange rate depreciation could play per se. 
real estate sector very often monopolized in the past the chances to get easy access to cheap external finance and use it to speculate on domestic financial assets.

Finally, manufacturing GDP share is affected negatively by the size of the domestic natural resources sector, here represented by the capital stock $K_{N R}$ invested in the natural resources industry.

Our analysis also rests on the well-known literature attributing specific growthenhancing properties to manufacturing. This standpoint dates back to the theoretical contributions by Nicholas Kaldor and it is also a central pillar of the structuralist theory. More recently, this perspective has been formally reinterpreted in several models on the natural resource curse (Sachs and Warner, 2001; Ros, 2001). From an empirical perspective, Imbs and Warzciag (2003) and Klinger and Lederman (2004) note that the development process significantly hinges upon the diversification of a country's productive structure. Manufacturing provides more opportunities than other sectors in terms of innovation, enlargement of the production space, and export diversification. Consequently, manufacturing development represents a "positive" structural change that feeds growth and economic take off (Rodrik, 2009; Rajan and Subramanian, 2011).

Equation (5) formalizes the essence of the Kaldorian and structuralist arguments on the pro-growth properties characterizing manufacturing. We assume a positive relationship between manufacturing GDP share $m$ and the overall labor productivity growth rate $y_{l}$.

(5) $y_{l}=g(m)$ with $\frac{\partial y_{l}}{\partial m}>0$ and $\frac{\partial\left(\partial y_{l} / \partial m\right)}{\partial m}<0$

On the basis of equations (4) and (5), the long-run development effects of the Dutch disease-cum-financialization phenomenon we analyze are depicted in Figure 3. In the top-left panel of Figure 3, we put in relation those values of the exchange rate $e$ and net portfolio capital flows $W A_{P I}$ that keep the manufacturing GDP share constant. According to the signs of the partial derivatives' to equation (4), the locus for constant $m$ values slopes upwards. In Figure 3, the " $m_{A}$ curve” represents all possible $e$ - W $A_{P I}$ combinations that keep the manufacturing GDP share equal to $m_{A}$, i.e., its initial value in the equilibrium point $A$. Points below (above) the " $m_{A}$ curve" stand for levels of manufacturing development lower (higher) than $m_{A}$. According to equation (4), the position of the map of contour curves for different $m$ values depends on $\rho$ and $K_{N}$. Should $\rho$ and/or $K_{N}$ increase, the isocline for values of $m$ equal to $m_{A}$ will move upwards. The top-right panel of Figure 3 depicts the positive relationship between the nominal exchange rate $e$ and $m$ as encapsulated in equation (4). Ultimately, the bottom-left panel of Figure 3 reproduces the positive link between manufacturing development and the overall labor productivity growth.

Now let us assume that a natural resources boom attracts new FDIs. The capital stock $K_{N R}$ increases and natural resources production and exports expand. Ceteris paribus, this implies a direct contraction of the manufacturing GDP share. 
In the top-left panel of Figure 3, this shock is represented by a parallel upward shift of the " $m_{A}$ isocline" (from $m_{A}$ to $m_{A}{ }^{1}$ ).

Apart from this first direct effect, the medium-run cyclical dynamics described above is portrayed in the top-left panel of Figure 3 by the black dotted line. The economy moves away from the initial equilibrium $A$ and fluctuate around the final equilibrium $B$. According to such a cyclical traverse towards the new equilibrium, increasing exchange rate volatility takes place, and $\rho$ increases in equation (4). Such heightened exchange rate volatility jeopardizes manufacturing development even further. In the top-left panel of Figure 3, a perverse second-round upward shift in the " $m_{A}$ isocline" (from $m_{A}{ }^{1}$ to $m_{A}{ }^{2}$ ) occurs.

Figure 3: Medium-to-long-run effects of Dutch disease cum financialization

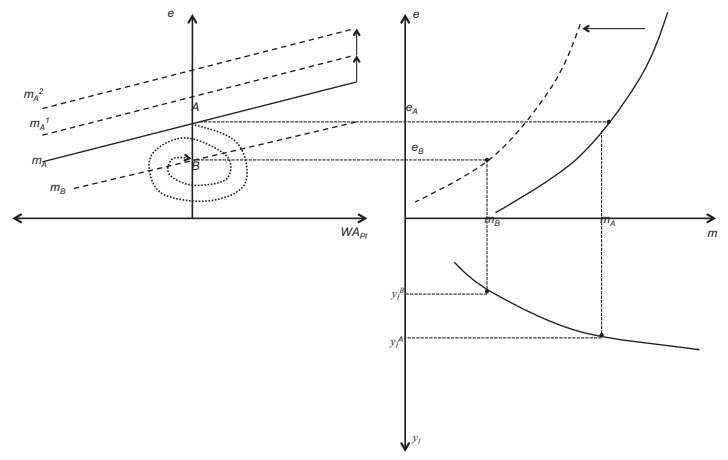

In the new equilibrium point $B$, following Bresser-Pereira (2008, 2010, 2013), the increasing exploitation and exports of primary commodities lead the exchange rate $e$ to assume a new and permanently more appreciated long-run value than the initial one. This is the standard Dutch disease-linked cause of de-industrialization.

In the top-right panel of Figure 3 we reproduce the long-run contraction of domestic manufacturing in the $(e-m)$ space. The leftward movement of the $(e-m)$ curve represents the effects on manufacturing development due to both the initial FDI shock, and the ensuing financialization-led exchange rate and macroeconomic volatility. The downward movement along the new dashed line from $e_{A}$ to $e_{B}$ is the outcome of the long-run Dutch disease-led exchange rate appreciation. Manufacturing participation to GDP eventually drops from $m_{A}$ to $m_{B}$.

Consistently with our assumptions, in the bottom-left panel of Figure 3 we show how a perverse mix of Dutch disease and financialization can eventually lead to a permanent slowdown in the growth rate of labor productivity (from $y_{l}^{A}$ to $y_{l}^{B}$ ) by impeding manufacturing development (or inducing de-industrialization) to take place.

\section{POLICY OPTIONS AND CONCLUSIONS}

This paper analyzes a complex nest between Dutch disease and financialization (including the Colombian one), which is generally overlooked by the standard lit- 
erature. Therefore, we consider two different but connected macroeconomic policies that might be useful to tackle the above Dutch-disease-cum-financialization phenomenon. We jointly take into account financial flow controls and the exchange rate policy implemented by domestic monetary authorities.

The exchange rate fluctuations we describe originate from a vicious spiral between volatile capital flows and exchange rate dynamics. The destabilizing effects of short/medium-term capital flights are clear. This paper provides further support to the already existing convincement that short/medium-term foreign portfolio investment should be tightly controlled. In particular, it might be useful to sharply reduce the sensitiveness of capital flows to exchange rate changes through taxation schemes that target and possibly squeeze capital gains emerging from the appreciation of the exchange rate.

In order to clarify this point, let us assume that policy intervention is successful in removing destabilizing connections between portfolio foreign investment and the exchange rate. The locus for $(\dot{D}=0)$ gets vertical (see Figure 4). On top of this, the locus for $(\dot{e}=0)$ may turn out to be positively sloped. Once removed destabilizing forces connecting $e$ to $\dot{e}$ through the dynamics in portfolio capital flows, a depreciation of the exchange rate will more easily improve the trade account and the overall BoPs, provided that the Marshall-Learner condition holds true. In this new framework, the "pure" Dutch disease still appreciates the exchange rate, hence undermining the competitiveness of domestic manufacturing. Yet, exchange rate volatility and developing country-type Minskyan cycles are avoided. The system becomes stable. This positively affects long-run economic development and the relative expansion of manufacturing by providing a more stable and safer context for taking long-term often irreversible investment decisions.

Figure 4: Capital flows' controls and macroeconomic stabilization

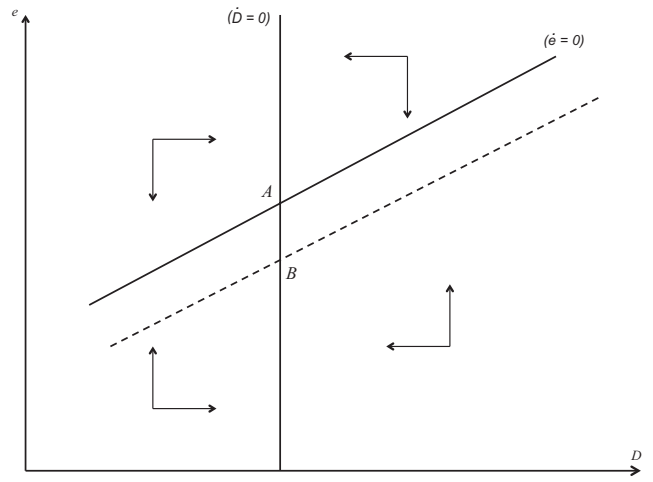

In spite of a much more stable macroeconomic environment, the Dutch disease and FDI-induced pressures on long-run exchange rate appreciation still continue to jeopardize manufacturing development. In order to effectively face this problem, the domestic central bank could intervene on the currency market and avoid nominal appreciation by increasing its own foreign reserves. A rise in $\dot{R}$ will help to bring 
the isocline for $(\dot{e}=0)$ back to its original position or shift it upward in Figure 4 . The domestic exchange rate could thus remain constant or even depreciate. Perverse effects of the Dutch disease and natural resource-oriented FDI on the competitiveness of domestic manufacturing could be neutralized or even reverted.

More generally, we consider an economic scenario in which a Dutch disease and FDI-induced initial surplus in the external account drives home currency to appreciate. According to Frenkel (2008), this is the context in which the well-know trilemma does not hold true. The domestic central bank can in fact intervene on the currency market, accumulate foreign reserves, maintain an independent monetary policy, and manage the exchange rate according to its own objectives even in presence of unfettered capital movements.

Such a monetary policy stance largely departs from a strict inflation targeting monetary policy. Monetary policy should pursue a wider range of goals far beyond price stability (which, in turn, is to pursue through a more general tight coordination between monetary, fiscal and social policies). Domestic monetary authorities should be actively involved in fostering the home-economy long-run development by recognizing the importance that the exchange rate plays to favor productive and export diversification. They should take a much more developmentalist stand and support domestic production development by targeting an international competitive real exchange rate through the management of the nominal one (Bresser-Pereira, 2010). In presence of both long-run phenomena (the Dutch disease and natural-resource-oriented FDI) and medium-run ones (a surge in portfolio investment), this goal should be pursued by promptly and aggressively piling up foreign reserves. In the case of Colombia, this has been done relatively late, in 2014 only. Much more should have been done as soon as the first signs of the Dutch disease manifested and capital inflows surged, this way appreciating the exchange rate since the beginning of the 2000s. A prompt and more active use of (Colombian) foreign reserves as policy tool to manage the exchange rate would have avoided the long-run appreciation of the Colombian pesos, preserved the competitiveness of Colombian manufactured goods, possibly maintained a close-to-equilibrium current account, and helped to avoid medium-run exchange rate volatility and macroeconomic instability.

Past experience has revealed that exchange rate pegs are very likely to give rise to speculative attacks and cannot protect developing countries from the risks posed to economic development by appreciating real exchange rates. Inflation targeting monetary policy and market-driven exchange rate fluctuations, however, seem not to provide a reliable alternative, as exchange rate and macroeconomic volatility can be rather high and pressures on nominal and real exchange appreciation persist. In other words, the best BoPs/exchange rate regime seems to be a managed, and sometimes strictly managed exchange rate regime in which domestic monetary authorities target a competitive and stable real exchange rate in order to favor growth and employment (Ocampo, 2013). There exists increasing consensus that this kind of policy has proven effective for a number of East Asian countries (Gala, 2008; Cimoli et al., 2013), and that they could work well to tackle the undesirable me- 
dium and long-run effects of a Dutch disease-cum-financialization phenomenon. This paper contributes to provide theoretical support to such positions.

\section{REFERENCES}

Bresser-Pereira, L. C. (2008). 'The Dutch disease and its neutralization: a Ricardian approach'. Brazilian Journal of Political Economy 28 (1): 47-71

Bresser-Pereira, L. C. (2010). Globalization and Competition. New York: Cambridge University Press.

Bresser-Pereira, L. C. (2013). 'The value of the exchange rate and the Dutch disease'. Brazilian Journal of Political Economy 33 (3): 371-387.

Bresser-Pereira, L. C., Oreiro, J.L., and Marconi, N. (2014). Developmental Macroeconomics. London: Routledge.

Bruno, M., and Sachs, J.D. (1982). 'Energy and Resource Allocation: A Dynamic Model of the "Dutch Disease", Review of Economic Studies 49 (5), 845 - 859.

Cimoli, M., Fleitas, M., and Porcile, G. (2013). 'Technology Intensity of the Export Structure and the Real Exchange Rate', Economics of New Technology and Innovation 22 (4), 353 - 372.

Corden, W.M., and Neary, J.P. (1982). 'Booming Sector and De-industrialization in a small open economy', The Economic Journal 92 (368), 825 - 848.

Epstain, G., and Yeldan A.E. (2009). 'Beyond Inflation Targeting: Assessing the Impacts and Policy Alternatives'. In: Beyond Inflation Targeting, eds. Epstain, G., and A.E. Yeldan, 3 - 27, Cheltenham (UK) and Northampton (USA): Edward Elgar.

Fang, W., Lai, Y., and Miller S.M. (2009). 'Does Exchange Rate Risk Affect Exports Asymmetrically? Asian Evidence'. Journal of International Money and Finance 28 (2): 215 - 239.

Frenkel, R. (2008) 'Competitive Real Exchange rate Regime, Inflation, and Monetary Policy', Cepal Review 96, 191 - 201.

Frenkel, R., and Rapetti, M. (2009). 'A Developing Country View of the Current Global Crisis: What should not be forgotten and what should be done', Cambridge Journal of Economics 33 (4), 685 -702 .

Gala, P. (2008). 'Real Exchange Rate Levels and Economic Development: Theoretical Analysis and Econometric Evidence', Cambridge Journal of Economics 32 (2): 273 - 288.

Goda, T., and Torres, A. (2013). 'Overvaluation of the Real Exchange rate and the Dutch Disease: The Colombian Case', CIEF Working Paper no 28-13.

Harvey, J.T. (2010). Modeling Financial Crises: A schematic Approach. Journal of post-Keynesian Economics $33(1), 61-82$.

Klinger, B., and Lederman, D. (2004). 'Discovery and Development: An Empirical Exploration of New Products', World Bank Policy Research Paper no 3450.

Imbs, J., and Warzciag, R. (2003). 'Stages of Diversification'. American Economic Review 93 (1), 63 - 86. IMF. (2015). IMF Country report on Colombia n. 15/142, June 2015.

Mansoorian, A. (1991). 'Resource Discoveries and Excessive External Borrowing', The Economic Journal 101 (409), 1497-1509.

Mishkin, F.S. (2000). 'Inflation Targeting in Emerging Market Countries', NBER Working Paper no 7618.

Neftci, S.N. (1998). 'FX Short Positions, Balance Sheets and Financial Turbulence: An Interpretation of the Asian Financial Crisis', CEPA Working Paper no 11.

Ocampo, J.A. (2013). 'Balance of Payments Dominance. Its Implications for Macroeconomic Policy', IPD Working Paper (October 2013).

OECD. (2013). 'OECD Economic Assessment of Colombia 2013'.

Oreiro, J.L., Basilio, F., and Souza, G. (2014). 'Effects of Overvaluation and Exchange Rate Volatility over Industrial Production: Empirical Evidence and Economic Policy Proposals for Brazil'. Brazilian Journal of Political Economy 34 (3): 347 - 369. 
Rajan, R.G., and Subramanian, A. (2011). 'Aid, Dutch Disease and Manufacturing Growth', Journal of Development Economics 94 (1), 106 - 118.

Rodrik, D. (2007). 'Industrial Development: Some Stylised Facts and Policy Directions'. In UN-DESA, (ed.), Industrial Development for the 21st Century: Sustainable Development Perspectives, New York: UN Publishing.

Rodrik, D. (2008a). 'The Real Exchange Rate and Economic Growth', Brookings Papers on Economic Activity 39 (2), $365-439$.

Rodrik, D. (2009). 'Growth After the Crisis', CEPR Discussion Paper no 7480.

Ros, J. (2001). 'Industrial Policy, Comparative Advantages and Growth', CEPAL Review 73, 127 - 145.

Sachs, J.D., and Warner, A. M. 2001. 'The Curse of natural resources', European Economic Review 45 (4), 827-838.

Singh, A. (2003). 'Capital Account Liberalization, Free long-term Capital Flows, Financial Crises and Economic Development', Eastern Economic Journal 29 (2), 191 - 216.

Taylor, L. (1983). Structuralist Macroeconomics: Applicable Models for the Third World, New York: Basic Books Publishers.

Taylor, L. (1991). Income Distribution, Inflation, and Growth. Cambridge, MA, USA: MIT Press.

Taylor, L. (1998). 'Capital Market crises: Liberalization, Fixed Exchange Rates and market-driven destabilization', Cambridge Journal of Economics 22 (6), 663 - 676.

Taylor, L. (2004). 'Reconstructing Macroeconomics', Cambridge, Massachusetts (USA) and London: Harvard University Press.

The Economist Intelligence Unit. 2013. Latin America as an FDI Hotspot: Opportunities and Risks. Available at: http://www.eiu.com/landing/special_reports. 